\title{
HUBUNGAN KECERDASAN EMOSIONAL TERHADAP KEMAMPUAN PEMECAHAN MASALAH MATEMATIKA SISWA KELAS V SD MUHAMMADIYAH I REMU SORONG
}

\author{
Inda I. R., Ahmad Y., \& Yannika N. \\ Program Studi Pendidikan Guru Sekolah Dasar, \\ Universitas Pendidikan Muhammadiyah (UNIMUDA) Sorong \\ Indahiriani9@gmail.com,
}

\begin{abstract}
Abstrak. Penelitian ini dilakukan dengan tujuan untuk mengetahui hubungan kecerdasan emosional terhadap kemampuan pemecahan masalah matematika siswa kelas V SD Muhammadiyah I Remu Sorong. Rancangan yang digunakan dalam penelitian ini adalah penelitian korelasi yang bertujuan untuk mengetahui hubungan antara dua variabel ( variabel X kecerdasan emosional terhadap variabel Y kemampuan pemecahan masalah). Pupolasi dalam peneltian ini adalah siswa kelas V SD Muhammadiyah I Remu Sorong yang berjumlah 115 siswa dan sampel yang digunakan berjumlah 39 siswa. Pengumpulan data pada penelitian ini menggunakan instrument tes sebagai alat untuk mengumpulkan data.Untuk mengolah data menggunakan sistem komputerisasi SPSS versi 16.0. Berdasarkan hasil penelitian, dapat disimpulkan bahwa ada hubungan yang signifikan antara kecerdasan emosional dengan kemampuan menyelesaikan masalah matematika siswa kelas V SD Muhammadiyah I Remu Sorong, yaitu sebesar 0,792 atau berkontribusi sebesar 79,20\%.
\end{abstract}

Kata kunci : Kecerdasan Emosional, Kemampuan Pemecahan Masalah.

Abstract. This study was conducted with the aim to determine the relationship between the wrong intelligence of fifth grade elementary school Muhammadivah I Re Design which was used in this study is correlation research which aims to determine the relationship between two variables (variable $\mathrm{X}$ emotional intelligence to variable $\mathrm{Y}$ problem solving ability). Muhammadiyah I Remu Sorong Elementary School totaling 115 students and the sample used was 39 students. Data collection in this study uses a test instrument as a tool for collecting data. To process data using the SPSS version 16.0 computerized system. Based on the results of the study, it can be concluded that there is a significant relationship between emotional intelligence and the ability to solve mathematical problems in fifth grade students of SD Muhammadiyah I Remu Sorong, which is equal to 0.792 or contributes $79.20 \%$

Keywords : Emotional Intelligence, Mathematical Problem Solving 


\section{PENDAHULUAN}

Undang-undang Sistem Pendidikan Nasional (SISDIKNAS) Nomor 20 Tahun 2003 merupakan awal perubahan pendidikan yang mencoba menyeimbangkan pola pembangunan SDM dengan mengedepankan Kecerdasan Spriritual (SQ), Kecerdasan Emosi (EQ), dan tidak mengabaikan Kecerdasan Intelektual (IQ). Karena adanya ketidakseimbangan antara kecerdasan intelektuan dan kecerdasan emosional, banyak ditemui anak cerdas yang sangat memprihatinkan. Yang disebabkan karena pertumbuhan kecerdasan intelektual anak yang dipaksakan tanpa memperhatikan kecerdasan emosional anak yang semakin rendah.

Kecerdasan emosional mempunyai peranan penting dalam kehidupan anak, namun sangat jarang ditemukan adanya pendidikan tentang kecerdasan emosi yang mengajarkan tentang: integritas, kejujuran, visi, kreativitas, mental, kebijakan, penguasaan diri, dan masih banyak lagi. Kecerdasan emosional merupakan kepekaan mengenali dan mengelola perasaan sendiri dan orang lain dan kepekaan dalam mengelola perasaanperasaan ini kemudian menjadi kerangka dalam berperilaku, bersosialisasi atau mengambil keputusan yang terjadi(Amalia, 2017). Kesimpulannya adalah kecerdasan emosional merupakan kemampuan untuk mengendalikan emosi yang ada didalam dirinya, memotivasi diri sendiri, memiliki kepekaan terhadap emosi orang lain, selalu berpikir positif, kemampuan mengatur kondisi emosinya baik dalam mengambil keputusan untuk diri sendiri ataupun kepada orang lain dengan kesadaran diri, serta dapat memecahkan masalah yang dihadapi dengan kondisi diri yang stabil.

Kemampuan pemecahan masalah merupakan hal yang sangat penting untuk diketahui siswa baik di dalam sekolah maupun dalam kehidupan sehari-hari. Hal ini sesuai dengan pendapat (Elvira Riska Harahap1, 2017) pemecahan masalah (problem solving) adalah suatu usaha atau aktifitas yang berhubungan dengan proses, seperti berfikir kritis, kreatif, reflektif dengan mencari masalah yang dihadapi, dan menemukan solusi atau jalan keluar dari masalah tersebut dengan kemampuan yang mereka miliki. Kesimpulannya kemampuan pemecahan masalah merupakan proses penerimaan tantangan atau upaya menemukan jalan keluar melalui proses yang terencana dalam menghadapi berbagai masalah baik masalah pribadi ataupun masalah kelompok untuk dipecahkan sendiri maupun bersama-sama.

Kemampuan pemecahan masalah menjadi tujuan dari pembelajaran matematika. Pembelajaran matematika di SD tidak hanya diarahkan pada peningkatan kemampuan siswa dalam berhitung, tetapi juga diarahkan kepada peningkatan kemampuan siswa dalam pemecahan masalah (Problem Solving), baik masalah matematika maupun masalah lain yang secara kontekstual menggunakan matematika untuk memecahkannya.

Berdasarkan uraian di atas, maka tujuan penelitian ini adalah untuk mencari hubungan kecerdasan emosional terhadap kemampuan pemecahan masalah matematika siswa kelas V. 


\section{METODOLOGI}

Jenis penelitian yang digunakan adalah pendekatan kuantitatif. Desain penelitian yang digunakan dalam penelitian ini adalah penelitian korelasi. Desain ini menggunakan dua variable yang terdiri dari satu variabel terikat dan satu variabel bebas.

Sumber: (Mulyatiningsih, 2013)

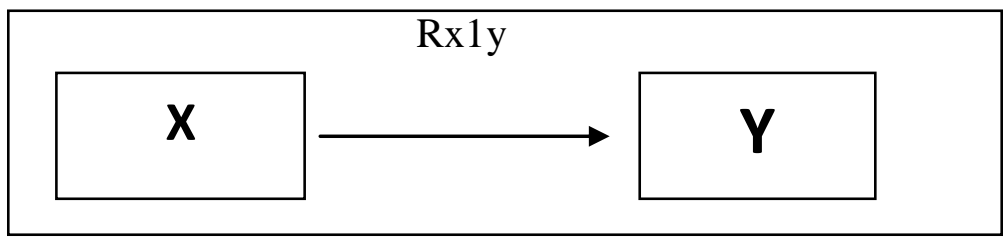

Gambar 3.1 Desain penelitian

Keterangan :

$\mathrm{X} \quad$ : Kecerdasan Emosional

Y : Kemampuan Pemecahan Masalah Matematika

Tempat penelitian ini dilaksanakan di SD Muhammadiyah I Remu Sorong Jalan. Puyuh No. 04 Kota Sorong, Papua Barat pada kelas V A semester genap tahun ajaran 2018/2019. Populasi dalam penelitian ini adalah seluruh siswa kelas V SD Muhammadiyah I Remu Kota Sorong yang terdiri dari 3 kelas yaitu kelas VA, VB, dan VC. Teknik pengambilan sampel dalam penelitian ini menggunakan random sampling.

Metode pengumpulan data yang digunakan untuk mendapatkan data peneletian melalui tes dan kuesioner/angket. Tes digunakan untuk mengetahui kemampuan pemecahan masalah pada siswa. Kuesioner/angket dalam penelitian ini bertujuan untuk mengukur tingkat kecerdasan emosional siswa.

Teknik analisis data yang digunakan adalah uji analisis deskriptif, uji normalitas data, dan analisis kolerasi. Uji analisis deskripstif bertujuan untuk mendapatkan gambaran umum data penelitian. Uji normalitas data dilakukan untuk mengetahui normal tidaknya data yang akan dianalisis, dalam pengujian ini menggunakan kolmogorov-smirnov. Sedangkan uji kolerasinya menggunakan teknik Product Moment analisis ini digunakan untuk mengetahui ada atau tidaknya hubungan antara dua variabel, kecerdasan emosional (X) dan kemampuan pemecahan masalah Matematika (Y) siswa kelas V SD Muhammadiyah I Remu Kota Sorong.

\section{HASIL DAN PEMBAHASAN}

Untuk mendapatkan data dari variable kecerdasan emosional (X) peneliti menggunakan aspek-aspek kecerdasan emosional yang dijawab oleh siswa. Dengan aspek kecerdasan emosional yaitu megenali emosi diri, mengelola emosi, memotivasi diri sendiri, mengenali emosi orang lain dan membina hubungan. Adapun skala kecerdasan emosional terdiri dari 40 item pernyataan (20 item pernyataan positif dan 20 item pernyataan negatif). Dalam penelitian ini subjek penelitian sebanyak 39 siswa. Adapun perbandingan tingkat kecerdasan emosional dapat dilihat pada tabel dibawah ini: 


\begin{tabular}{|c|c|c|c|}
\hline \multirow[b]{2}{*}{ No } & \multicolumn{3}{|c|}{ Tabel 1. Kategori Kecerdasan Emosional } \\
\hline & $\begin{array}{l}\text { Tingkat Kecerdasan } \\
\text { Emosional }\end{array}$ & $\begin{array}{c}\text { Jumlah } \\
\text { Frekuensi }\end{array}$ & Presentase (\%) \\
\hline 1. & Sangat Baik & 7 & 17.9 \\
\hline 2. & Baik & 27 & 69.2 \\
\hline \multirow[t]{2}{*}{3.} & Cukup Baik & 5 & 12.8 \\
\hline & Jumlah & 39 & 100.0 \\
\hline \multirow{2}{*}{\multicolumn{4}{|c|}{$\begin{array}{l}\text { Untuk memperoleh data tentang kemampuan menyelesaikan masalah } \mathrm{m} \\
\text { siswa diperoleh dari tes yang diberikan oleh peneliti. Tes berupa tes uraian } \\
\text { kemampuan menyelesaikan masalah matematika dapat dilihat pada tabel dibawah } \\
\text { Tabel 2. Kategori Kemampuan Menyelesaikan Masalah Matematika Siswa }\end{array}$}} \\
\hline & & & \\
\hline No & Kategori Kemampuan Pemecahan & Frekuensi & Persentase (\%) \\
\hline 1. & Baik Sekali & 6 & 15.4 \\
\hline 2. & Baik & 7 & 17.9 \\
\hline 3. & Cukup & 17 & 43.6 \\
\hline 4. & Kurang & 5 & 12.8 \\
\hline 5. & Kurang Sekali & 4 & 10.3 \\
\hline & Jumlah & 39 & 100.0 \\
\hline
\end{tabular}

\section{Hubungan Kecerdasan Emosional dan Kemampuan Menyelesaikan Masalah Matematika}

Untuk mencari hubungan antara kecerdasan emosional dan kemampuan menyelesaikan masalah matematika siswa maka akan dilakukan analisis korelasi. Analisis korelasi yang dilakukan menggunakan bantuan program SPSS 16. Analisis korelasi yang digunakan adalah korelasi Product Moment. Hasil olahan data dapat dilihat sebagai berikut..

Tabel 3. Hasil Uji Kolerasi

\begin{tabular}{|ll|r|r|}
\hline & $\begin{array}{c}\text { Kecerdasan } \\
\text { Emosional }\end{array}$ & $\begin{array}{c}\text { Kemampuan } \\
\text { Pemecahan } \\
\text { Masalah }\end{array}$ \\
\hline Kecerdasan Emosional & Pearson Correlation & 1 & .792 \\
& Sig. (2-tailed) & 39 & .000 \\
& $\mathrm{~N}$ & .792 & 39 \\
\hline Kemampuan Pemecahan & Pearson Correlation & .000 & 1 \\
& Sig. (2-tailed) & 39 & 39 \\
& $\mathrm{~N}$ & & \\
\hline
\end{tabular}


Sehingga dapat disimpulkan bahwa $\mathrm{H}_{\mathrm{o}}$ ditolak dan $\mathrm{H}_{\mathrm{a}}$ diterima. Hal ini dikarenakan $\mathrm{p}<0,01(0,000<0,01)$ maka hal ini berarti kecerdasan emosional memiliki hubungan terhadap kemampuan menyelesaikan masalah pada siswa kelas $\mathrm{V}^{\mathrm{A}}$ SD Muhammadiyah I Remu Sorong.

\section{KESIMPULAN}

Berdasarkan hasil penelitian yang telah dilakukan, maka dapat disimpulkan bahwa ada hubungan yang sangat signifikan antara kecerdasan emosional dengan kemampuan menyelesaikan masalah, hal ini di buktikan dengan nilai hasil koefisien korelasi yang menunjukan angka 0,792 dengan nilai sig.0,000 dimana $\mathrm{p}<0,05$. Artinya semakin tinggi kecerdasan emosional pada siswa, maka semakin baik kemampuan menyelesaikan masalah pada siswa tersebut. Sebaliknya, semakin rendah kecerdasan emosional siswa, maka kemampuan menyelesaikan masalah semakin rendah. Kemampuan menyelesaikan masalah sangat mempengaruhi kecerdasan emosional karena telah dibuktikan oleh hasil penelitian yang dilakukan di SD Muhammadiyah I Remu Sorong. Siswa yang memiliki kecerdasan emosional yang baik dapat menyelesaikan masalahnya sendiri, begitu pun kemampuan menyelesaikan masalah yang baik dihasilkan dari kecerdasan emosional. Kecerdasan emosional sangat dipengaruhi oleh lingkungan, tidak bersifat menetap, dapat berubahubah. Untuk itu peranan lingkungan terutama orang tua pada masa kanak-kanak sangat mempengaruhi pembentukan kecerdasan emosional. (Goleman, 2017) mendefinisikan kecerdasan emosional sebagai serangkaian kemampuan pribadi, emosi dan sosial yang mempengaruhi kemampuan seseorang untuk berhasil dalam mengatasi tututan dan tekanan lingkungan.

\section{Saran}

\section{Bagi subjek penelitian}

Diharapkan subjek penelitian/siswa meningkatkan kecerdasaan emosional yang tinggi agar dapat meningkatkan lagi tingkat kemampuan menyelesaikan masalah dan tetap bersemangat dalam menyelesaikan tugas- tugas yang diberikan oleh pendidik.

\section{Bagi Guru-guru SD Muhammadiyah I Remu Sorong.}

Diharapkan guru-guru agar dapat memberi siswa support yang baik dalam proses pembelajaran, dengan cara memberikan nasehat, arahan dan perhatian agar tingkat kecerdasan emosional siswa selalu stabil dan akan menjadikan siswa mampu dalam menyelesaikan masalah yang sedang dihadapi.

\section{Bagi Penelitian Selanjutnya}

Diharapkan penelitian selanjutnya yang tertarik meneliti tentang hubungan kecerdasan emosional dengan kemampuan menyelesaikan masalah pada siswa diharapkan untuk mencari teori yang lebih baru terhadap kedua variabel penelitiaan ini, dan diharapkan juga untuk memperhatikan variabel luaran yang memiliki hubungan yang lebih kuat dengan variabel yang hendak di teliti, serta dapat melakukan uji coba skala dengan 
jumlah item yang lebih banyak lagi, dengan responden berbeda dan jumlah responden yang lebih banyak, dan berikanlah pengarahan agar subjek mengisi skala yang disediakan sesuai dengan yang mereka alami.

\section{DAFTAR RUJUKAN}

[1] Amalia, W. (2017). Hubungan Antara Kecerdasan Emosional dengan Kemampuan Menyelesaikan Masalah Pada Siswa Sma Aisyiyah 1. Jurnal Pendidikan, 1-116.

[2] Elvira Riska Harahap1, E. S. (2017). Kemampuan Pemecahan Masalah Matematis Siswa Kelas Vii Dalam Menyelesaikan Persamaan Linear Satu Variabel. Jurnal Pendidikan, 07(April), 44-54.

[3] Goleman. (2017). Emotional Intelligence,Jakarta (Gramedia Pustaka Utama).

[4] Mulyatiningsih, D. E. (2013). Metode Penelitian Terapan Bidang Pendidikan.Bandung : Alfabeta 